\title{
Detection of marine birnavirus in the Japanese pearl oyster Pinctada fucata and seawater from different depths
}

\author{
Shin-Ichi Kitamura', Yuji Tomaru ${ }^{2}$, Zen'ichiro Kawabata ${ }^{3}$, Satoru Suzuki ${ }^{1, *}$ \\ ${ }^{1}$ Center for Marine Environmental Studies, Ehime University, Matsuyama 790-8577, Japan \\ ${ }^{2}$ National Research Institute of Fisheries and Environment of Inland Sea, Ohno, Hiroshima 739-0452, Japan \\ ${ }^{3}$ Center for Ecological Research, Kyoto University, Otsu 520-2113, Japan
}

\begin{abstract}
This study examines the seasonal changes of marine birnavirus (MABV) in seawater and the Japanese pearl oyster Pinctada fucata reared at different depths (2 and $15 \mathrm{~m}$ ). Oysters and seawater were collected in 1998, and a 2-step PCR was carried out to detect MABV. Virus isolation was performed on the PCR-positive samples in the oyster. The detection rate of the MABV genome in the oyster was low during June, but increased after July at both 2 and $15 \mathrm{~m}$ depths. MABV was not isolated until after September, when isolation rates of 10 to $28.6 \%$ were recorded. The results suggest that growth of MABV in the oyster is similar at 2 and $15 \mathrm{~m}$ depth. In contrast, the MABV genome in seawater was present through the year at $15 \mathrm{~m}$ depth, but was not detected in summer at $2 \mathrm{~m}$. This suggests that the virus is destroyed by UV and/or other factors at $2 \mathrm{~m}$ in summer, but is stable in deeper waters.
\end{abstract}

KEY WORDS: Birnavirus · Japanese pearl oyster $\cdot$ Uwa Sea $\cdot$ Seawater $\cdot$ Depth

\section{INTRODUCTION}

Mass mortality of cultured Japanese pearl oysters Pinctada fucata occurred in western Japan from 1994 to 1999. Many researchers have investigated the cause of this mortality from various standpoints such as infectious diseases, lack of planktonic food, and pollution of the farming area (Miyazaki et al. 1999, Tomaru et al. 2001), but the real cause remains unclear. During an etiological survey, we isolated a marine birnavirus (MABV) from a symptomatic oyster (Suzuki et al. 1998a). This MABV strain was designated JPO-96, and its virulence against the Japanese pearl oyster was found to be weak (Suzuki et al. 1998b). However, the susceptibility of hard clams Meretrix lusoria to a Taiwanese strain of birnavirus has been reported to increase under stressful conditions, such as unsuitable

*Corresponding author. E-mail: ssuzuki@agr.ehime-u.ac.jp temperature and pollution by heavy metals (Chou et al. 1994, 1998). Moreover, spawning stress increased mortality through MABV in the bivalve Agemaki Sinonovacura consticta from Korea (Suzuki et al. 1997b). These findings suggest that MABV is an opportunistic pathogen against shellfish. In order to prevent MABV disease, it is first necessary to determine the ecology of the virus not only in its hosts but also in the surrounding environment. Therefore, in 1997, we surveyed the seasonal occurrence of MABV in the Japanese pearl oyster and the environmental seawater (Kitamura \& Suzuki 2000, Kitamura et al. 2000). We found that the MABV infection rate of the oyster and the viral protein concentration in the seawater increased during fall and winter, when temperatures were low.

Generally, Japanese pearl oysters are cultivated at $2 \mathrm{~m}$ depth in the Uwa Sea, Ehime Prefecture, Japan. The oysters are cleaned regularly and all attached benthic organisms are removed. Before surgical seeding of pearl, the oysters are moved to $15 \mathrm{~m}$ depth to 
lower their metabolism activity. This handling is stressful, and it is therefore imperative to determine which environmatental conditions cause them least stress. Although MABV is not a strong pathogen of the oyster, ecological surveys of MABV under various environmental conditions are needed to prevent the occurrence of the disease. In this study, we investigated the occurrence of MABV in seawater and oysters cultivated at different depths (2 and $15 \mathrm{~m})$. Genomic changes in isolated strains were also examined.

\section{MATERIALS AND METHODS}

Sampling. Japanese pearl oysters Pinctada fucata were collected at the Uwa Sea, Ehime Prefecture (Fig. 1). The oysters were transported to the sampling station from another area of the Uwa Sea in June, 1998.

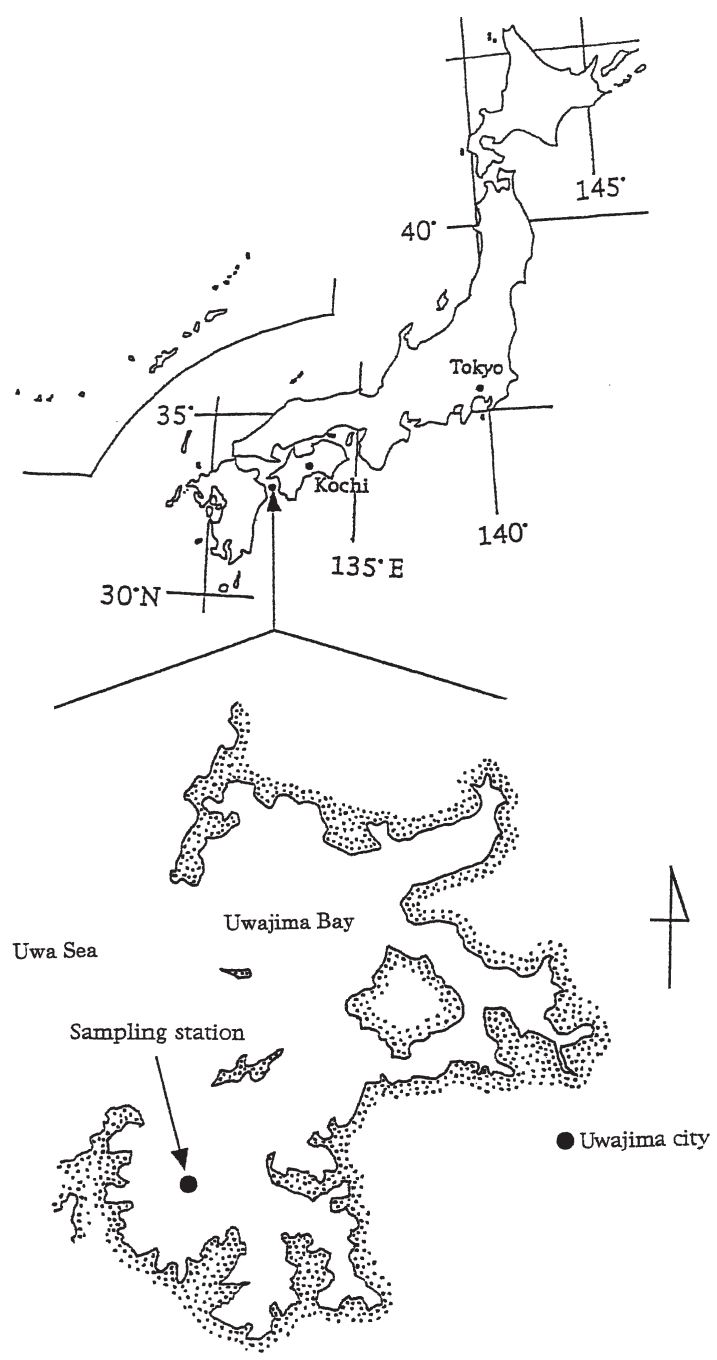

Fig. 1. Map showing sampling station of Japanese pearl oysters in the Uwa Sea, Japan
They were placed in net cages hung at 2 and $15 \mathrm{~m}$ depths. During normal cultivation, the surface of the oyster shell is cleaned every 2 wk to remove fouling organisms. In the present study, the oysters were divided into 2 groups, one group was not cleaned throughout the experimental period, the other was cleaned every month. The oysters were sampled in June, July, September and November 1998; their body weight and that of fouling organisms were measured. The mortality of the oysters was monitored throughout the experimental period.

Seawater samples were collected with a Niskin sampler from 2 and $15 \mathrm{~m}$ depths at the oyster farm.

Physico-chemical and biological data. Seasonal changes in the water temperature and salinity at 2 and $15 \mathrm{~m}$ depths were measured with a Chlorotech ACL208-DK (Arec Electronics) profiler. The concentration of dissolved oxygen (DO) at these depths was determined by the Winkler method (Grasshoff 1983). Gross production and primary production were determined by the oxygen method (Wetzel \& Likens 1990); the incubation time was ca. $6 \mathrm{~h}$ (between 09:00 and 15:00 h). A $100 \mathrm{ml}$ water sample from each depth was filtered through a $0.2 \mathrm{~mm}$ pore Nuclepore filter to retain seston. Chlorophyll a concentration was determined by the fluorometric method (Rami \& Porath 1980).

Two-step PCR. RNA extraction and PCR were performed by the method of Suzuki et al. (1997a). Briefly, $0.2 \mathrm{~g}$ of hepatopancreas was taken from each oyster and was homogenized in a 4-fold volume of TE (0.2 M Tris $\mathrm{HCl}, \mathrm{pH} 8.3,0.1 \mathrm{M}$ EDTA) followed by centrifugation at $3000 \times g$ for $5 \mathrm{~min} ; 45 \mu$ of supernatant was removed to a new eppendorf tube and $5 \mu \mathrm{l}$ of Proteinase $\mathrm{K}$ (1 $\mathrm{mg} \mathrm{ml}^{-1}$, TaKaRa Co.) was added thereto. The supernatant was then incubated at $55^{\circ} \mathrm{C}$ for $2 \mathrm{~h}$. Nucleic acids were extracted using the phenol-chloroform method. The nucleic acid fraction was heated at $100^{\circ} \mathrm{C}$ for $5 \mathrm{~min}$, and a primer set of $\mathrm{P} 1-\mathrm{P} 2$ (P1: 5' -AGAGATCACTGACTTCACAAGTGAC-3'; P2: 5' -TGTGCACCACAGGAAAGATGACTC-3') was added, following reverse transcription performed with Moloney murine leukaemia virus reverse transcriptase (MMLV, GIBCO) at $37^{\circ} \mathrm{C}$ for $1 \mathrm{~h}$. To inactivate the reverse transcriptase, the sample was heated at $100^{\circ} \mathrm{C}$ for $5 \mathrm{~min}$. The synthesized cDNA was diluted 10 -fold and used for PCR. PCR amplification was performed in a DNA thermal cycler (TaKaRa), with 30 amplification cycles $\left(95^{\circ} \mathrm{C}\right.$ for $1 \mathrm{~min}, 50^{\circ} \mathrm{C}$ for $1 \mathrm{~min}$, $72^{\circ} \mathrm{C}$ for $\left.1 \mathrm{~min}\right)$. For the nested-PCR, $3 \mu \mathrm{l}$ of the RT-PCR product was used. In conclusion, nested amplification was carried out with a cycle of $95^{\circ} \mathrm{C}$ for $1 \mathrm{~min}, 48^{\circ} \mathrm{C}$ for $1 \mathrm{~min}$, and $72^{\circ} \mathrm{C}$ for $1 \mathrm{~min}$ with a primer set of P3-P4 (P3: 5'-CAACACTCTTCCCCATG-3'; P4: 5'-AGAACCTCCCAGTGTCT-3'). The purity and size of the amplified products were analyzed by electrophoresis on 
$2 \%$ agarose gel. The gels were stained with ethidium bromide and visualized under UV light.

Nucleotide sequencing. From the PCR-positive products each month, 1 sample was randomly chosen for nucleotide sequencing. Sequencing was based on the dideoxy nucleotide termination method (Sanger et al. 1977) in an automated DNA sequencer (373A: Applied Biosystems) using the ABI PRISM ${ }^{\mathrm{TM}}$ Dye Terminator Cycle Sequencing Kit with AmpliTaq DNA polymerase (Perkin Elmer). Analysis of the results was performed using Genetyx Mac Version 7.3 software.

Cell culture. The chinook salmon embryo cell line (CHSE-214) was used for isolation and quantitative analysis of the virus. The cells were grown at $20^{\circ} \mathrm{C}$ in Eagle's minimum essential medium (MEM, Nissui) containing $10 \%$ fetal bovine serum (FBS).

Virus isolation was carried out for the PCR-positive samples. The hepatopancreas was homogenized in a 4-fold volume of Hank's balanced salt solution (Nissui) using a stomacher 80T (Seward), and the homogenate was centrifuged at $3000 \times g$ at $4^{\circ} \mathrm{C}$ for $15 \mathrm{~min}$. The supernatant was filtered through a $0.45 \mu \mathrm{m}$ pore filter (Millipore), and 5 and $20 \mu \mathrm{l}$ portions of the filtrates were inoculated to a monolayer of CHSE-214 cells cultured in 24-well tissue-culture plates (Sumilon), which were incubated at $20^{\circ} \mathrm{C}$ for $2 \mathrm{wk}$. The cytopathic effect (CPE) was monitored daily. Virus titration of the original samples was performed by the tissue-culture infection dose $\left(\mathrm{TCID}_{50}\right.$ ) method, and the infectivity titer was calculated by the method of Reed \& Muench (1938) using a 96-well tissue culture plate (Sumilon).

Detection of MABV genome in seawater. Virus concentration followed the method of Kitamura \& Suzuki (2000). Briefly, 1 l of seawater was collected and $100 \mu \mathrm{M}$ sodium azide was added to inactivate microbial activity. The sample was transported to the laboratory on ice within a few hours of collection. The water was passed through a $0.20 \mu \mathrm{m}$ filter. To remove the salt, $10 \mathrm{ml}$ of seawater was dialyzed against distilled water at $4^{\circ} \mathrm{C}$ overnight. Distilled water was changed 3 times. To concentrate the virus, a dialyzed sample was employed for ethanol precipitation with twice the volume of ethanol, and centrifugated at $8000 \times g$ at $4^{\circ} \mathrm{C}$ for $1 \mathrm{~h}$. The precipitant was washed with $70 \%$ ethanol and centrifugated at $18000 \times g$ at $4^{\circ} \mathrm{C}$ for $15 \mathrm{~min}$. This precipitant was employed for the 2-step PCR. In the case of a PCR-positive result, the relative amount of the PCR-product was estimated from the image intensity of the ethidium bromide stained gel using a luminous imager (AISIN COSMOS).

\section{RESULTS}

\section{Physico-chemical and biological data}

The basic physico-chemical and biological data for the sampling station are shown in Table 1. The water temperature reached a maximum in September, and a thermocline was observed from June to September. The water temperature in November was isothermal, probably due to vertical mixing. The DO content at $2 \mathrm{~m}$ depth was highest in June, but decreased in July and September because of an increase in the phytoplankton population which consumed DO. Salinity was fairly constant during the study period. Chlorophyll a concentration was highest in September. Both gross and net production at $2 \mathrm{~m}$ depth were higher than at $15 \mathrm{~m}$ depth from June through September, and vice versa in November.

\section{Oyster growth and mortality}

When fouling organisms were not removed from the shell, body weight of the oysters decreased from and average of 48.21 to $40.85 \mathrm{~g}$ at $2 \mathrm{~m}$, and from 42.58 to $36.92 \mathrm{~g}$ at $15 \mathrm{~m}$, although these decreases were not significant (Fig. 2A). On the other hand, when fouling organisms were removed regularly, body weight increased from 46.80 to $60.89 \mathrm{~g}$ at $2 \mathrm{~m}$, but did not change at $15 \mathrm{~m}$ from June through November (Fig. 2B). Fouling organisms increased in weight to $69.42 \mathrm{~g}$ at $2 \mathrm{~m}$ and $45.74 \mathrm{~g}$ at $15 \mathrm{~m}$ during this period (Fig. 2C). The fouling organisms were mainly algae at $2 \mathrm{~m}$, but barnacles were predominant at $15 \mathrm{~m}$. The cumulative

Table 1. Basic physico-chemical and biological data at 2 and $15 \mathrm{~m}$ depths at the sampling station in the Uwa Sea in 1998. DO: dissolved oxygen; nd: not determined

\begin{tabular}{|c|c|c|c|c|c|c|c|c|c|c|c|c|}
\hline \multirow[t]{3}{*}{ Month } & \multicolumn{2}{|c|}{ Water temp. $\left({ }^{\circ} \mathrm{C}\right)$} & \multicolumn{2}{|c|}{$\mathrm{DO}\left(\mathrm{mg} \mathrm{l}^{-1}\right)$} & \multicolumn{2}{|c|}{ Salinity (mg l-1) } & \multicolumn{2}{|c|}{ Chl a $\left(\mu g \mathrm{l}^{-1}\right)$} & \multicolumn{4}{|c|}{ Production $\left(\mu \mathrm{g} \mathrm{O}_{2} \mathrm{l}^{-1} \mathrm{~h}^{-1}\right)$} \\
\hline & \multirow[t]{2}{*}{$2 \mathrm{~m}$} & \multirow[t]{2}{*}{$15 \mathrm{~m}$} & \multirow[t]{2}{*}{$2 \mathrm{~m}$} & \multirow[t]{2}{*}{$15 \mathrm{~m}$} & \multirow[t]{2}{*}{$2 \mathrm{~m}$} & \multirow[t]{2}{*}{$15 \mathrm{~m}$} & \multirow[t]{2}{*}{$2 \mathrm{~m}$} & \multirow[t]{2}{*}{$15 \mathrm{~m}$} & \multicolumn{2}{|c|}{ Gross } & \multicolumn{2}{|c|}{ Net } \\
\hline & & & & & & & & & $2 \mathrm{~m}$ & $15 \mathrm{~m}$ & $2 \mathrm{~m}$ & $15 \mathrm{~m}$ \\
\hline Jun & 22.59 & 20.48 & 8.04 & 6.89 & 33.05 & 33.74 & 2.65 & 0.92 & 56 & 9 & 26 & -6 \\
\hline Jul & 24.46 & 22.92 & 7.11 & 6.47 & 33.49 & 33.78 & 1.71 & 0.49 & 33 & nd & 19 & 11 \\
\hline Sep & 25.24 & 24.85 & 7.02 & 6.38 & 33.53 & 33.65 & 15.04 & 4.28 & 324 & 10 & 26 & -18 \\
\hline Nov & 20.09 & 20.09 & 6.32 & 6.34 & 33.86 & 33.86 & 0.74 & 0.70 & 18 & 27 & 7 & 19 \\
\hline
\end{tabular}



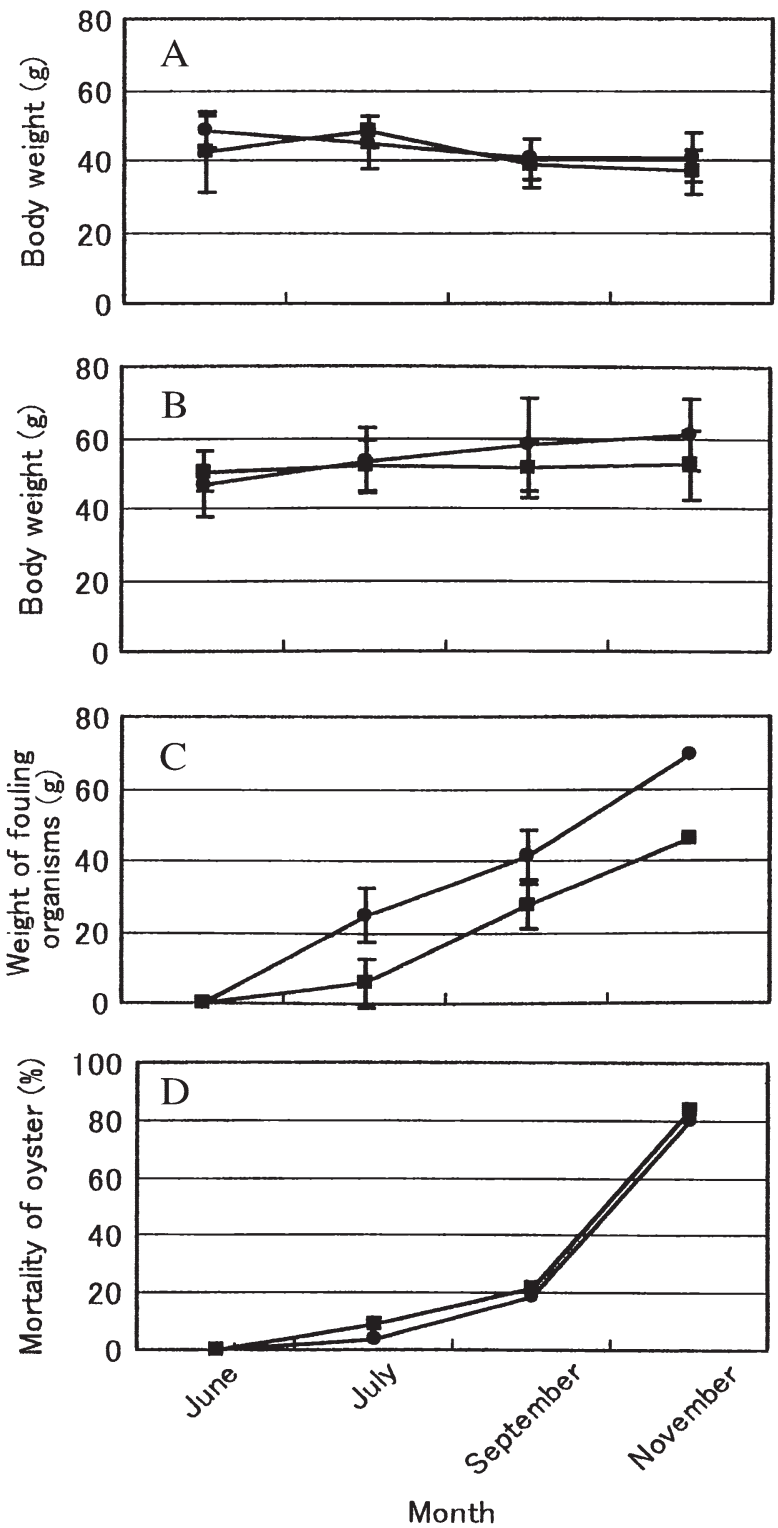

Fig. 2. Body weight of (A) uncleaned oysters, and (B) oysters cleaned regularly throughout the experimental period. (C) Weight of fouling organisms attached to the oysters; (D) cumulative mortality. (•) $2 \mathrm{~m}$ depth; (•) $15 \mathrm{~m}$ depth

Table 2. Isolation of marine birnavirus from Japanese pearl oysters, showing detection rate (no. of oysters positive) and virus titer $\left(\mathrm{TCID}_{50} \mathrm{~g}^{-1}\right)$. nd: not determined

\begin{tabular}{|lcccc|}
\hline \multirow{2}{*}{ Month } & \multicolumn{2}{c}{$2 \mathrm{~m}$} & \multicolumn{2}{c|}{$15 \mathrm{~m}$} \\
& Rate & Titer & Rate & Titer \\
\hline Jun & nd & - & nd & - \\
Jul & $0 / 10$ & - & $0 / 10$ & - \\
Sep & $2 / 7$ & $10^{5.5}$ & $0 / 9$ & - \\
& & $10^{3.3}$ & & \\
Nov & $2 / 10$ & $10^{5.5}$ & $1 / 10$ & $10^{3.3}$ \\
& & $10^{4.3}$ & & \\
\hline
\end{tabular}

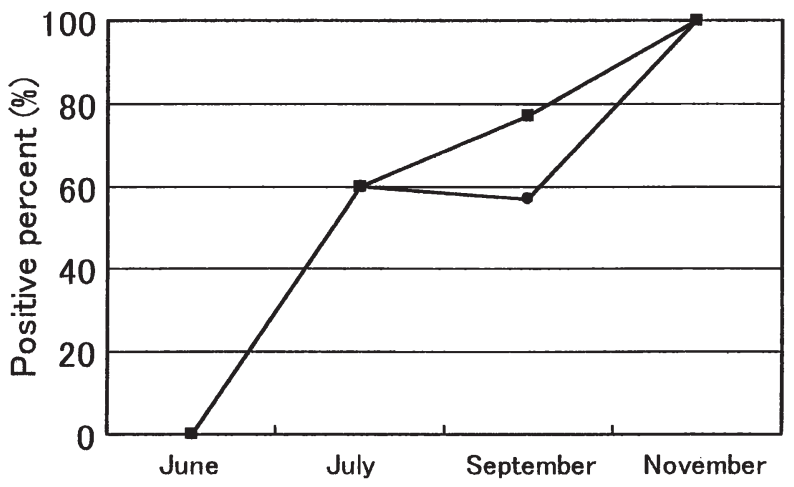

Fig. 3. Detection rate of MABV genome in non-cleaned Japanese pearl oysters by PCR. (•) $2 \mathrm{~m}$ depth; (ロ) $15 \mathrm{~m}$ depth

mortality of non-cleaned oysters increased to $70 \%$ in November at both depths (Fig. 2D).

\section{Detection of viral genome in the oyster}

The results of the 2 step-PCR detection of the MABV genome in the non-cleaned oysters are shown in Fig. 3. The MABV genome was not detected in June, but the detection rate increased after July by more than $50 \%$. Detection profiles at the 2 depths were similar throughout the survey period.

\section{Virus isolation and titration}

For the PCR-positive samples, virus isolation was carried out using CHSE-214 cells. The virus was not isolated in samples in June and July, but was isolated from samples collected after September (Table 2). Isolation rates were 0 to $28.6 \%$. The infectivity titers per gram hepatopancreas tissue were $10^{3.3}$ to $10^{5.5} \mathrm{TCID}_{50}$. Among the isolates, 1 strain in September was designated as JPO-98, and its PCR product was sequenced.

\section{Nucleotide sequence}

Among the PCR-positive products, 1 sample was randomly chosen each month for employing the nucleotide sequencing. The $134 \mathrm{bp}$ (except for primer length) of the nested-PCR product was sequenced, and the sequences of all samples proved to be the same. The sequence data were compared with data for other MABV strains (Fig. 4). In Strain JPO-96 (Suzuki et al. 1998a), the 126th base was $T$, whereas it was $C$ for JPO-98 in the present study, although there was no amino acid change. The sequence obtained in this study was identical to those of Strain JPO-97 isolated 
PCR product

(Jun.-Nov.) GCGGCACCAC TCATCGGAGC CGCCGACCAA TTCATCGGAG ACCTGACCAA 50

JPO-98 GCGGCACCAC TCATCGGAGC CGCCGACCAA TTCATCGGAG ACCTGACCAA

JPO $-97 \quad \ldots \ldots \ldots \ldots \ldots$

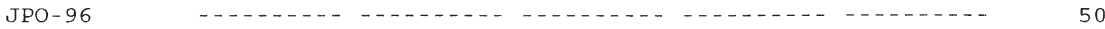

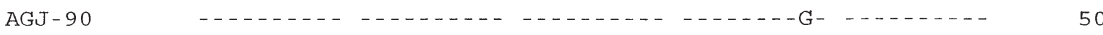

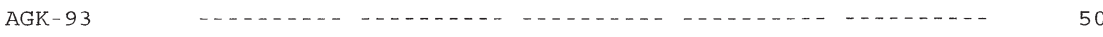

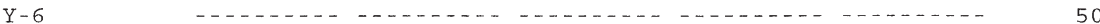

PCR product

(Jun.-Nov.) GACCAACGCA GCCGGAGGCC GCTACCTAAC ACATGCAGCA GGAGGACGCT 100

JPO-98 GACCAACGCA GCCGGAGGCC GCTACCTAAC ACATGCAGCA GGAGGACGCT 100

JPO-97

JPO-96

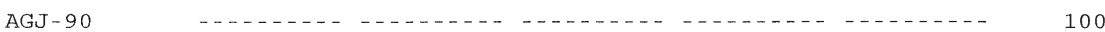

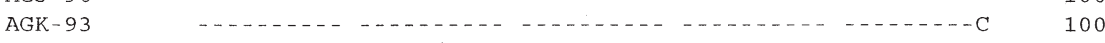

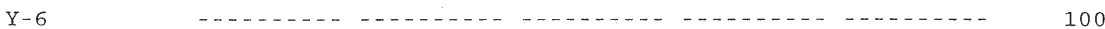

PCR product

(Jun.-NOV.) ACACTGACGT AATGGACTCC TGGGCCAGCG GCAC 134

JPO-98 ACACTGACGT AATGGACTCC T'GGGCCAGCG GCAC

JPO-97

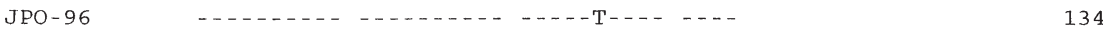

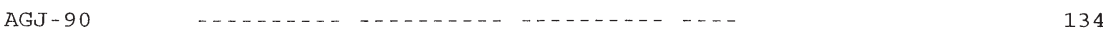

AGK-93

Y $-6 \quad \ldots \ldots \ldots \ldots \ldots \ldots \ldots$

Fig. 4. Nucleotide sequences of the 2-step PCR products and strain isolated (JPO-98). Sequences obtained in June to November were identical. Sequences for Strains JPO-97, JPO-96, AGJ-90, AGJ-93 and Y-6 are shown for comparison; dashes indicate same bases as for JPO-98

in 1997 (Kitamura et al. 2000) and of Strain Y-6, a strain isolated from a fish. In Strain AGJ-90 (Suzuki et al. 1997b) isolated from Agemaki Sinonovacura constrica, the 39th base was G, whereas it was A in the PCRproduct of this study. In Strain AGK-93 (Suzuki et al. 1997b), isolated from Agemaki (Korea), the 100th base, was $\mathrm{C}$, whereas it was $\mathrm{T}$ in the present study: only here did we note an amino acid change, i.e. $H$ in strain AGK-93 was Y in other strains.

\section{Detection of MABV genome in seawater}

The results of the 2 step-PCR of the virus from the seawater is shown in Fig. 5A. The MABV genome was detected in the samples of September and November from $2 \mathrm{~m}$ and in the samples of June through November from 15 $\mathrm{m}$, but was not detected in the June and July samples at $2 \mathrm{~m}$. Staining intensity was expressed as a relative amount using image scanning analysis (Fig. 5B), which revealed that the amount of MABV genome was stable at $15 \mathrm{~m}$, throughout the experimental period, but increased from September to November at $2 \mathrm{~m}$.

\section{DISCUSSION}

Human viruses such as hepatitis A virus, adenovirus, Norwalk-like virus, enterovirus, rotavirus and astrovirus have been reported in aquatic environments and shellfish (Tani et al. 1995, Pina et al. 1998). However, there are few reports on the virus ecology of fish and shellfish viruses. In order to control the epidemics of viral diseases, it is important to know the dynamics of the virus under various environmental conditions. The results in this paper clearly showed a seasonal change in MABV in the Japanese pearl oyster cultivated at different depths ( 2 and $15 \mathrm{~m}$ ) and in seawater.
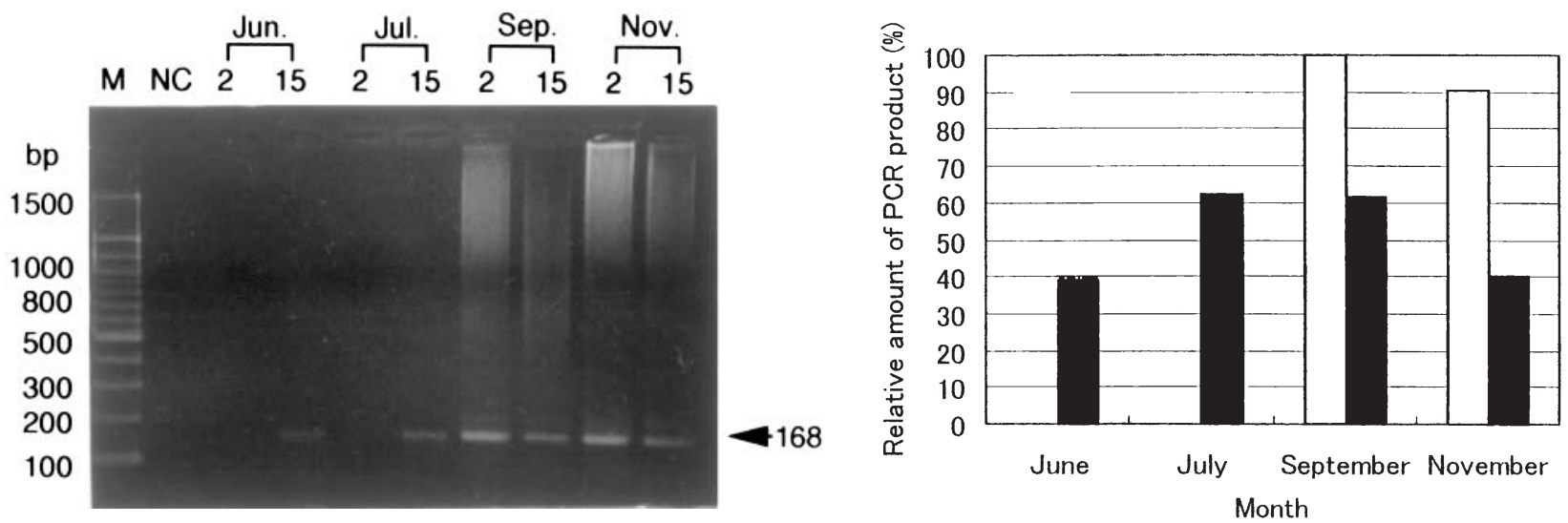

Fig. 5. (A) Detection of the MABV genome in seawater by 2-step PCR at 2 and $15 \mathrm{~m}$ depths; months are indicated above the representative lanes. M: molecular marker; NC: negative control without template. (B) Relative amount of PCR product (\%). September product expressed as $100 \%$; white bar: $2 \mathrm{~m}$; solid bar: $15 \mathrm{~m}$ 
When the oyster shell was cleaned regularly, oyster weight increased more at $2 \mathrm{~m}$ depth than at $15 \mathrm{~m}$. The environmental factors affecting the health and growth of Japanese pearl oysters such as temperature, salinity and amount of plankton food available, have been reported (Numaguchi 1994a,b). Based on the results of Numaguchi's studies, water temperature and salinity were optimal throughout the experimental period in the present study. The amount of plankton food at $15 \mathrm{~m}$ was less than at $2 \mathrm{~m}$ from June through September, and the difference in oyster weight between 2 and $15 \mathrm{~m}$ depth probably arose from this difference in food availability. Fouling by algae ( $2 \mathrm{~m}$ depth) and barnacles (15 m depth) was observed, and this also affected food availability by slowing down filtration rates.

The percentage of oysters infected with MABV increased from fall to winter at both 2 and $15 \mathrm{~m}$ depth, as observed in an earlier study (Kitamura et al. 2000). A statistical analysis was not possible because of the small sample numbers, but isolation rate and virus infectivity in the oysters at 2 and $15 \mathrm{~m}$ appeared similar, suggesting that the replication rate of MABV in the oysters was similar at 2 and $15 \mathrm{~m}$. Since the water temperature differed little between 2 and $15 \mathrm{~m}$ throughout the experimental period, this might be the reason why MABV growth rates were similar at both depths. Sorimachi \& Hara (1985) reported that the optimum temperature for growth of yellowtail ascites virus (YAV) is $20^{\circ} \mathrm{C}$, and the YAV does not grow at $25^{\circ} \mathrm{C}$ in vivo or in vitro. Although the temperature in the Uwa Sea in September was higher than $24^{\circ} \mathrm{C}$, the detection rate of MABV did not decrease, indicating that MABV can grow at this temperature. We observed that MABV increased in yellowtail Seriola quiqueradiata at water temperatures higher than $25^{\circ} \mathrm{C}$ (data not shown). The temperature requirements of $\mathrm{MABV}$ may alter over time.

The MABV genome was not detected at $2 \mathrm{~m}$ in June and July, but was detected in September and November; this result was similar to previous data obtained in 1997 (Kitamura \& Suzuki 2000). On the other hand, the relative amount of the MABV genome in the PCR assay was constant at $15 \mathrm{~m}$, suggesting that the released virus and/or virus genome were destroyed by $\mathrm{UV}$ at $2 \mathrm{~m}$ in summer, but remained stable in deeper waters. Investigating the effect of UV on infectious pancreatic necrosis virus (IPNV), Yoshimizu et al. (1986) reported that more than $99 \%$ of the virus was inactivated by UV at 1.0 to $1.5 \times 10^{5} \mu \mathrm{W} \mathrm{s}^{-1} \mathrm{~cm}^{-2}$. The intensity of the UV of the sunlight entering the Uwa Sea should be quatified to determine the actual effect on the marine birnavirus. Virus destruction can also be caused by factors other than UV. For example, adsorption of the virus to particulate materials that can be taken up by other animals at specific depths.
The junction region between VP2 and NS is known to be variable, but is useful for genogrouping aquatic birnaviruses (Heppell et al. 1992, 1993, Hosono et al. 1996). To investigate mutation in the variable regions, we sequenced the VP2/NS region. The 134-long nucleotide was compared among strains originating from fishes and shellfishes. The sequences of the genome from seawater and Strain JPO-98 were identical to those of the JPO-97 and Y-6 strains. The highly conserved sequences among the MABVs suggest that the MABV may be genetically similar in western Japan.

Until now, ecological evidence of birnaviruses has not been thoroughly examined. The present study clearly indicates seasonal changes of MABV in seawater and Japanese pearl oysters cultivated at different depths (2 and $15 \mathrm{~m}$ ). In summary, seasonal changes in the occurrence of MABV in the oyster were similar at the 2 depths, i.e. MABV increased in the oyster from fall to winter. The relative amount of MABV genome in seawater was not detected at $2 \mathrm{~m}$ in June and July, but was constant at $15 \mathrm{~m}$. The sequence analysis of the MABV genome showed that the strain isolated in 1998 was genetically the same as the JPO-97 and Y-6 strains. We plan further ecological studies of MABV under various environmental conditions and host organisms.

Acknowledgements. We gratefully thank Ruth Vergin for her review of this manuscript. We also thank K. Kawai and S. Nakano for their encouragement throughout this study. This work was carried out in collaboration with Yusu Fisheries Corporation. This work was partly supported by a Grant-inAid from MESSC, Japan.

\section{LITERATURE CITED}

Chou YH, Li HJ, Lo CF (1994) Pathogenicity of a birnavirus to hard clam (Meretrix lusoria) and effect of temperature stress on its virulence. Fish Pathol 29:171-175

Chou YH, Chang SJ, Lee HY, Chiou YC (1998) Preliminary evidence for the effect of heavy metal cations on the susceptibility of hard clam (Meretrix lusoria) to clam birnavirus infection. Fish Pathol 33:213-219

Grasshoff K (1983) Determination of oxygen. In: Grasshoff K, Ehrhardt M, Kremling K (eds) Methods of seawater analysis. Verlag Chemie, Weinheim, p 61-72

Heppell J, Berthiaume L, Tarrab E, Lecomte J, Arella M (1992) Evidence of genomic variations between infectious pancreatic necrosis virus strains determined by restriction fragment profiles. J Gen Virol 73:2863-2870

Heppell J, Berthiaume L, Corbin F, Tarrab E, Lecomte J, Arella M (1993) Comparison of amino acid sequences deduced from a cDNA fragment from infectious pancreatic necrosis virus (IPNV) strains of different serotypes. Virology 195: $840-844$

Hosono N, Suzuki S, Kusuda R (1996) Genogrouping of birnaviruses isolated from marine fish: a comparison of VP2/NS junction regions on genome segment A. J Fish Dis 19:295-302

Kitamura SI, Suzuki S (2000) Occurrence of marine birnavirus 
through the year in coastal seawater in the Uwa Sea. Mar Biotechnol 2:188-194

Kitamura SI, Jung SJ, Suzuki S (2000) Seasonal change of infective state of marine birnavirus in Japanese pearl oyster Pinctada fucata. Arch Virol 145:2003-2014

Miyazaki T, Goto K, Kageyama T, Miyata M (1999) Mass mortalities associated with a virus disease in Japanese pearl oyster Pinctada fucata martensii. Dis Aquat Org 37:1-12

Numaguchi K (1994a) Effect of water temperature on the filtration rate of Japanese pearl oyster, Pinctada fucata martensii. Suisanzoshoku (Aquaculture, Tokyo) 42:1-6

Numaguchi K (1994b) Growth and physiological condition of the Japanes pearl oyster, Pinctada fucata martensii in Ohmura Bay, Japan. J Shellfish Res 13:93-99

Pina S, Puig M, Lucena F, Jofre J, Girones R (1998) Viral pollution in environment and in shellfish: human adenovirus detection by PCR as an index of human viruses. Appl Environ Microbiol 4:163-169

Rami M, Porath D (1980) Chlorophyll determination in intact tissues using $\mathrm{N}, \mathrm{N}$-dimethylformamide. Plant Physiol (Rockv) 65:478-479

Reed RJ, Muench H (1938) A simple method of estimating fifty percent endpoints. Am J Hyg 27:493-497

Sanger F, Nicklen S, Coulson AR (1977) DNA sequencing with chain-termination inhibitor. Proc Natl Acad Sci USA 75:5463-5467

Sorimachi M, Hara T (1985) Characteristics and pathogenicity of virus isolated from yellowtail fingerlings showing ascites. Fish Pathol 19:231-238

Editorial responsibility: Jo-Ann Leong,

Corvallis, Oregon, USA
Suzuki S, Hosono N, Kusuda R (1997a) Detection of aquatic birnavirus gene from marine fish using a combination of reverse transcription- and nested PCR. J Mar Biotechnol 5: 205-209

Suzuki S, Nakata T, Kamakura M, Yoshimoto M, Furukawa Y, Yamashita Y, Kusuda R (1997b) Isolation of birnavirus from Agemaki (jack knife clam) Sinonovacura constica and survey of the virus using PCR technique. Fish Sci (Tokyo) 63:563-566

Suzuki S, Kamakura M, Kusuda R (1998a) Isolation of birnavirus from Japanese pearl oyster Pinctada fucata. Fish Sci (Tokyo) 64:342-343

Suzuki S, Utsunomiya I, Kusuda R (1998b) Experimental infection of marine birnavirus strain JPO-96 to Japanese pearl oyster Pinctada fucata. Bull Mar Sci Fish Kochi Univ 18:39-41

Tani N, Dohi Y, Kurumatani N, Yonemasu K (1995) Seasonal distribution of adenoviruses and reoviruses in urban river water. Microbiol Immunol 39:577-580

Tomaru Y, Kawabata Z, Nakano S (2001) Mass mortality of the Japanese pearl oyster Pinctada fucata martensii in relation to water temperature, chlorophyll a and phytoplankton composition. Dis Aquat Org 44:61-68

Wetzel RG, Likens GL (1990) Primary productivity of phytoplankton. In: Wetzel RG, Likens GE (eds) Limnological analyses. Springer-Verlag, New York, p 207-211

Yoshimizu M, Takizawa H, Kimura T (1986) U.V. susceptibility of some fish pathogenic viruses. Fish Pathol 21: $47-52$

Submitted: July 24, 2001; Accepted: February 22, 2002 Proofs received from author(s): July 9, 2002 